\title{
Challenge of the Director of Pertamina in the Implementation of Corporate's Independence Principles and the Legal Doctrine Fiduciary Duty
}

\author{
Try Widiyono \\ Faculty of Law \\ Jakarta Islamic University \\ Jakarta, Indonesia \\ Journal.uid@gmail.com
}

\begin{abstract}
On April 11, 2018 PT Pertamina (Persero) had acquired State shares in PT National gas Company. Thus Pertamina has completed corporate action to become Oil and Gas Holding. Pertamina is a State-Owned Enterprise (BUMN) in the form of Limited Liability Company which is subject to Law Number 40 year 2007 regarding Limited Liability Company (UPT). In the UPT there is the principle of corporate independence and legal doctrine Fiduciary duty ie limited liability company is the cause for the existence (raison d'etre) of the Board of Directors which gave birth to "fiduciary duties" for the Board of Directors who must uphold professionalism and should not be interpolated by other parties. Based on legal research, normative results were presented in this paper. There are two principles that intersect the principle of oil and gas management, it should be used for the greatest prosperity of the people at the lowest possible price, so that there is interference of government. On the other side, the existence of independence Pertamina and Fiduciary duty law doctrine for Pertamina Board of Directors which should not be interfered in the management of Pertamina by anyone including oil and gas pricing. Therefore, the dilemma for Pertamina's Board of Directors is to harmonize the company's independence principle and Fiduciary duty's legal doctrine with the strong interference of the government as the shareholders in controlling the Pertamina Board of Directors, because Pertamina's commodity concerns the lives of many people, especially regarding the distribution and price of oil and gas. To terminate the dilemma for the Pertamina Board of Directors and Shareholders for strong allegations of violation of the doctrine is to amend and/or provide an explanation of Article 3 of Law no. 40 of 2007 on Limited Liability Company.
\end{abstract}

Keywords- Challenge, Pertamina Board of Directors, Corporate Independence and Fiduciary Duty

\section{INTRODUCTION}

Article 33 Paragraph (3) of the 1945 Constitution states that "Earth, water and natural resources contained therein are controlled by the state and used for the greatest prosperity of the people". Based on the dictum of Law No. 22 of 2001 on Oil and Gas stated that "Oil and Natural Gas are a nonrenewable strategic natural resources dominated by the state and is a vital commodity that controls the livelihood of many people and has an important role in the national economy. Therefore, its management must be able to maximally provide prosperity and prosperity of the people ". Based on these two legal sources, it means that oil and gas is a natural wealth that must be controlled by the state and utilized for the welfare of the people

The definition of "controlled by the state" in the two provisions mentioned above does not mean the State as the owner of Oil and Gas, but these two provisions provide authority and power to the state to regulate the allocation and use and management of oil and gas oriented to improve people's welfare. The function of such a state gives authority, among others, to determine the distribution and price of oil and gas fuel to be affordable by the people and for the welfare of all Indonesian people. Implementation of the State is as a regulator of the allocation and use and manages the oil and gas. The government has established Pertamina Company since $1957^{1}$ and has experienced several changes to the latest Articles of Association On December 14, 2015 when the Minister of State-owned enterprises (SOEs) as the General Meeting of Shareholders approved the amendment of Pertamina's Articles of Association optimization of resource utilization. The capital increase is placed and taken part by the state and the actions of the Board of Directors which require the approval of the Board of Commissioners. This amendment was declared in Deed No.10 dated January 11, 2016, drawn up by Notary Lenny Janis Ishak, SH. Furthermore, as a mandate of the Oil and Gas Law, on April 11, 2018, the Government has established oil and gas holding through PT Pertamina (Persero) ${ }^{2}$ as holding company and PT Perusahaan Gas Negara (PGN (National gas Company)) as a subsidiary. With the joining of $\mathrm{PGN}^{3}$, Pertamina currently has 22 direct subsidiaries, excluding the company's subsidiaries[1]. With the taking of State shares in PGN by Pertamina, PGN is no longer a state-owned company, as referred to in Law no. 19 of 2003 concerning State-Owned Enterprises jo Government Regulation no. 45 of 2001 on Persero. With the change of ownership of such shares, PGN's name should no longer use the title "Persero".

${ }^{1}$ On December 10, 1957, the company changed its name to PT Perusahaan MinyakNasional, abbreviated PERMINA. This date is celebrated as the birth of Pertamina to this day.

${ }^{2}$ As a follow up of PP. 6 Year 2018 on the Addition of State Equity Participation to PT PersamianPersero State (Persero) Company's Capital, on April 11, 2018 Minister of State-Owned Enterprises Mrs. Rini M Soemarno signed the State-owned Series B transfer deed of PT Peruhaan Gas Negara, Tbk (PGN) amounting to $56.96 \%$ to PT Pertamina. Thus PGN has become one of 22 subsidiaries of Pertamina.

${ }^{3}$ PT Perusahaan Gas Negara (PGN) will be synergized with PT Pertagas which has become a subsidiary of PT Pertamina. 
Pertamina has business activities in the field of energy business[1], namely oil and gas, new and renewable energy, and other activities related to or supporting business activities in the energy sector, namely oil and gas, renewable and renewable energy and the development of optimization of sources power owned by the Company. Pertamina's business activities, if associated with Article 33 paragraph (1) of the 1945 Constitution, are not solely oriented towards profitability, because Pertamina's business is a business concerning the livelihood of the people and should be able to prosper the people.

Pertamina is a State-Owned Enterprise $(B U M N)^{4}$ in the form of Limited Liability Company. Therefore, Pertamina is also subject to Law no. 40 of 2007 on Limited Liability Company Law (UPT). In the Limited Liability Company Law, there is a principle of independence[2] of the company apart from individual persons residing within the company including the company's organs ${ }^{5}$. The principle of independence of a limited liability company is that the company is an association of its members and separation between the company and its members. In addition, there is also the Fiduciary duty legal doctrine, Limited Liability Company is the cause for the existence (raison d'etre) of the Board of Directors and has a fiduciary relationship that gave birth to "Fiduciary Duties" for the Board of Directors[3]. Limited Liability Company is one form of profit-oriented business. Therefore, Pertamina is also required by shareholders to gain profit. Board of Directors as the management of the company must be professional to achieve the intention and business of the company to gain profit.

The two legal facts described above that the business of Pertaminan is related to Oil and Natural Gas that is owned by the State and must be utilized including the distribution and the price of Oil and Gas. It must be affordable for the welfare of the Indonesian people. While Pertamina as a limited liability company must gain profit and Pertamina Board of Directors should not be interfered by Government even as shareholder, including in business strategy, distribution and price of Oil and Gas.

Based on the above background, it can be formulated problems: How is the dilemma ofPertamina Board of Directors in applying the principle of independence of Limited Liability Company and legal doctrine Fiduciary duty sourced from the Law no. 40 year 2017 on Limited Liability Company?; How does the government intervene in determining the distribution and price of oil and gas managed by Pertamina?; and How should a positive legal norm be perfected to end up the dilemma of the Pertamina Board of Directors and shareholders (Government) in order not to violate the Principles of Independence of Limited Liability Company and legal doctrine Fiduciary duty?

\section{RESEARCH METHODS}

This research used normative legal research. It is a process to find out the rule of law, legal principles, and legal doctrines to answer the legal issues faced[4]. The legal issues

\footnotetext{
4 Based on Law No. 19 of 2003 on State Owned Enterprises jo PP No. 45 of 2001 on Persero, the definition of State-Owned Enterprises is a company whose shares are 51 or more owned by the State and PT Pertamina (Persero) shares of $99 \%$ owned by the State.

5 Article 1 number 2 UPT Organs of Limited Liability Companies are General Meeting of Shareholders, Board of Directors and Board of Commissioners
}

in this study are as presented in the formulation of the above problems.

The legal issue was revealed through a process of discovering the legal norms that should be established, covered by the rule of law, legal principles and legal doctrine. Therefore, the process of legal research is in line with the opinion that legal research is a process to find the rule of law, legal principles and legal doctrine. In this legal research the process was to find the rule of law, legal principles and legal doctrine about the existence of Pertamina's holding and challenges Pertamina Board of Directors in applying the principle of independence of Limited Liability Company and Fiduciary duty law doctrine.

The rule of law is established by the authorities through the agency or body authorized for it, while the rule of law is the values underlying the legal norms. The legal doctrine is the legal source of the jurists. This research also want to test the normative postulate of legal norms (postulates/propositions) contained in Limited Liability Law on the existence of Pertamina Holding. Legal provision in the Limited Liability Lawis as a major premise while minor premise is a legal fact[4]. In this case the relevant legal facts. In the end legal research is conducted to reveal the above mentioned legal issues whose outcome is to provide a description of what is ought to be.

\section{RESULTS AND DISCUSSION}

\section{A. Independence of Limited Liability Company}

Salomon v. Salomon co.Ltd's decision in 1897 in the United Kingdom, which in essence was a lawsuit from minority shareholders (not from the Solomon family) to the majority shareholder of the Solomon family as well as the Board of Directors of the company, for the Solomon family to be personally liable for the loss of the company, because the company's assets were still lacking to pay the company's debt. The minority shareholders transferred the company to the Solomon family company, so the Solomon family had to bear the loss. The plaintiff's claim is rejected by the Court because the company is a separate entity from the shareholders and its directors. Since then, limited liability is a common principle in the modern world that shareholders in a Limited Company cannot be held accountable beyond their share of capital[5]. This principle is then known as the principle of company as separate legal entity[5].

Chidir Ali points out the elements that are the criteria for determining a legal entity, among others (i) separate assets; (ii) having a specific purpose; (iii) has its own interests (iv) organizational existence[5]. The separation of private property is important, to convince the legal parties with the legal entity. The other party needs to know the responsibilities of the management and shareholders of the agreement, in addition to knowing the authority to act. The legal entity is autonomous (independent) separate from its management. The nature of this legal entity must be distinguished from non-legal entity, such as the Civil Society (maatschap), Limined Partnership (commanditairevennootschap) and the Firm which is still a unity and inseparable part of its board which is essentially united to the legal subject of the person or the manager. The business entity, not a legal entity. Because the legal entity has independence in performing legal acts and separated with the management[6]. 
Limited Liability Company is a legal entity this is contained in Article 1 point 1 UPT stating "Limited Liability Company is a legal entity which is a partnership of capital, established under the agreement, conducting business with the authorized share capital wholly divided into shares, and meet the requirements stipulated in this law and its implementing regulations ". Therefore, the aspect of separation of personal property (separate legal personality) which contains the independence of limited company has been regulated in the UPT and become an important part for the existence of Limited Liability Company.

The principle of independence is also reinforced in Article 3 Paragraph (1) The Limited Liability Law states, "The shareholders of the Company shall not be personally liable for any engagement made on behalf of the Company and shall not be liable for any loss of the Company's shares." Immunity of shareholders becomes invalid when an event is provided in Article 3 paragraph (2) Limited Liability Law, namely (a). the requirements of the Company as a legal entity have not been or have not been met; (b). the shareholders concerned directly or indirectly in good faith utilize the Company for personal benefit; (c). the relevant shareholder is engaged in an unlawful act committed by the Company; or (d). shareholders concerned directly or indirectly against the law using the Company's assets, resulting in the Company's insufficient wealth to repay the Company's debt.

Article 1 Sub-Article 4 of the UPT states that "General Meeting of Shareholders which further the GMS is an organ of a company with authority not authorized to the Board of Directors or Board of Commissioners within the limits stipulated in this Law and/or AD". This means that UPT (Limited Liability Law) has authorized shareholders to be able to interfere in the management of the company through the General Meeting of Shareholders. The intervention is limited to the authority set forth in the UPT. This means that the General Meeting of Shareholders has limited authority and still holds firmly to the intent and purpose of the company.

Based on the above description, it can be concluded that the principle of independence of a limited liability company is a principle which originates from the company as a legal entity having separate assets with assets owned by shareholders, Board of Directors and Board of Commissioners. Hence, it cannot be interfered, except through the General Meeting of Holders Shares to achieve the company's intentions and business by not violating the prevailing laws and regulations. Therefore, the Limited Independence Company Principles described above must be upheld by Pertamina either as a Limited Liability Company or as Holding. Pertamina's Shareholder, the Government, even as a $99.9 \%$ shareholder, must refrain from applying this principle to avoid loss of shareholder immunity.

\section{B. The legal doctrine of Fiduciary duty}

The limited liability company as a separate legal entity possesses the legal doctrine that must be implemented, namely the Fiduciary Duty law doctrine.[6] Henry Campbell Black stated "Fiduciary duty, it is a duty to act for someone else's benefit, while subordinating one's personal interest to that of the person. It is the higheststandard of duty implied by law[7]. Another opinion states "Limited Company is the cause of existence (raison d'etre) for the Board of Directors.
Therefore, between the Limited Company and the Board of Directors there is a fiduciary relationship that gives birth to "Fiduciary Duties" for the Board of Directors"[3].

Actions for and on behalf of others in Limited Liability Companies granted to the Board of Directors shall be carried out with the highest standards of law. Since the Board of Directors is the trust of the shareholders. However, the Board of Directors shall not only be responsible to shareholders, but shall be responsible to all stakeholders. The Board of Directors shall depart from the basis that the duties and positions derived are based on two basic principles, namely the first fiduciary duty and the duty of skill and care[8]. Meanwhile, I.G.RayWidjaya stated that the Board of Directors' duty is to manage the company. The task is the task of management and representation tasks (representing the company) I.G.RayWidjaya, divides into 3 (three) duties of the Board of Directors namely fiduciary duties, trust and confidence; based on skill, caution and diligence and statutory duties[9].

The Fiduciary duty legal doctrine in the UPT is set forth in Article 1 Sub-Article 5 states that "The Board of Directors is the Company's organ of authority and fully responsible for the maintenance of the Company for the interest of the Company, in accordance with the purposes and objectives of the Company and representing the Company, both inside and outside the court in accordance with provisions of articles of association. Article 1 point 5 The UPT grants full authority and responsibility for the management of the company in accordance with the intent, purpose and business of the company and represents the company, both inside and outside the court in accordance with the provisions of the articles of association.

Article 1 point 5 The UPT is an application of fiduciary duty principle to the directors to manage the company professionally and responsibly not only to shareholders but also to stakeholders. Therefore, based on the fiduciary duty doctrine, the directors of the company must refuse to interfere the shareholders in the management of the company including directing and/or influencing the company to perform certain actions that are contrary to the principle[6].

Another provision in the UPT related to the fiduciary duty doctrine is Article 92 paragraph (1) which states that the Board of Directors performs the Company's management for the interest of the Company and in accordance with the purposes and objectives of the Company. Paragraph (2) The Board of Directors is authorized to exercise the management as referred to in paragraph (1) in accordance with the policy deemed appropriate, within the limits specified in this Law and/or the articles of association. Subsequently Article 97 Paragraph (1) states that the Board of Directors is responsible for the management of the Company as referred to in Article 92 paragraph (1). Paragraph (2) states that the Management as referred to in paragraph (1) shall be executed by each member of the Board of Directors in good faith and with full responsibility. The Paragraph (3) states that each member of the Board of Directors shall be fully liable individually for the loss of the Company if he is guilty or negligent perform their duties in accordance with the provisions referred to in paragraph (2).

Thus, it can be concluded that the fiduciary duty doctrine is a doctrine which authorizes the Directors to administer the company according to the Company's purpose, business and 
objectives set forth in the Articles of Association professionally, ethically and by upholding Good Corporate Gouvance (GCG) with full responsibility. This means that the board of directors of the company shall refuse to interfere with the shareholders in the management of the company including directing and/or influencing the company to perform certain actions that are contrary to such doctrine including Pertamina's Board of Directors.

The legal doctrine of Fiduciary duty as described above must be upheld by the Pertamina board of directors. Pertamina Board of Directors must perform the fiduciary provided to run Pertamina stewardship with professionals and with high standards to achieve the goals and objectives of Pertamina company and can be held accountable to stake holders and not just to share holder only. The Board of Directors of Pertaminashall refuse to participate in the distribution and price of Oil and Gas determined by the Shareholder if violated this doctrine. The sanction of the Pertamina Board of Directors against this violation is personally liable. Based on the Collegial Principles for the Board of Directors of the Company, if there are more than one member of the Board of Directors, all members of the Board of Directors are jointly responsible unless they can prove that it is not their fault.

\section{Oil and Gas for the Welfare for Indonesian Citizens}

Talcot Parson a sociologist as the founder of "Theory of Cybernetics" suggested that the law consists of sub-systems of economic sub-systems, political sub-systems, social subsystems and cultural sub-systems. Each sub-system is intertwined and interplayed[10]. The opinion is in line with Roscoe pound on law as a tool of social engineering that law is a tool for engineering society. Each sub-system produces resultant results between the respective sub-systems of economic, political, social and cultural. So it is related to Pertamina as a profit-oriented company with its business commodities in the form of oil and gas related to the economy of the livelihood of many people, giving birth to the interest between law, politics, hope and reality to maintain its ideology. The Government's expectation of Pertamina as a source of State revenue through Oil and Gas is faced with oil and natural gas commodities as a commodity for people's lives.

Independence of the Unitary State of the Republic of Indonesia based on the Constitution of 1945, was established among others to form the State of Welfare (welfare state). The welfare state is a country in which the state government is held responsible for ensuring a minimum welfare standard for every citizen[11]. Furthermore the concept of welfare state departs from the state's efforts to manage all existing resources in order to achieve one of the state's goals of improving the welfare of its people[11]. Therefore, the welfare to be realized by the Republic of Indonesia is the welfare of all the people of Indonesia.

Article 33 Paragraph (3) of the 1945 Constitution "The earth, the water and the natural resources contained therein are controlled by the state and used for the greatest prosperity of the people". The function of state control can be interpreted (i) to organize and administer its designation, use, inventory and maintenance; (ii) Determine and regulate the rights which may belong to that part of the earth, water and space; (iii). Determine and regulate legal relationships concerning earth, water and space.[6]
The 1945 Constitution has provided an adequate basis for the State/Government to and must utilize natural resources in the territory of the Republic of Indonesia used for the welfare of all Indonesian people, including oil and natural gas. Oil and gas commodities shall be regulated and administered for their use, use, stock and maintenance by the State. This means there is a State intervention in managing oil and natural gas. Such interventions are included in the distribution and determination of the price of oil and natural gas

Based on legal doctrine and legal theory as well as legal facts as mentioned above, there is a conflicting doctrine between one another and each must be run by the Pertamina Board of Directors, namely the principle of independence of a limited liability company for Pertamina and Fiduciary Duty Doctrine for Pertamina Board of Directors dealing with the Government's interference and the government's interference with the Pertamina Board of Directors in relation to the establishment of oil and gas commodities for the welfare of the whole Indonesian people.

The principle of independence of a limited liability company is essentially the principle derived from the company as a legal entity having separate assets with assets owned by the shareholders, the Board of Directors and the Board of Commissioners. Thus, it cannot be interfered, except through the General Meeting of Shareholders to achieve the purpose and business of the company with no violation of applicable laws and regulations. The limits of authority of Shareholders in the General Meeting of Shareholders are set forth in Article 3 of the UPT described above

Pertamina is a national energy company $100 \%(99.9 \%)$ owned by the Government of the Republic of Indonesia, through the Ministry of State-Owned Enterprises (SOEs) as the Proxy of Shareholders[12]. Therefore, the Government as Pertamina shareholder is obliged to respect and run the principle of independence of Pertamina as an independent entity. This means that shareholders (government) may not interfere in the management of Pertamina in accordance with the purpose and objectives and pertamina business as stipulated in the Articles of Association and the applicable laws and regulations. Violation of the principle of independence of a limited liability company, the immunity of the shareholders of the Company as regulated in Article 3 paragraph 1 of UPT shall not apply. This means that the shareholder (Government) becomes responsible for the engagement made on behalf of Pertamina and is responsible for Pertamina's losses

The ban on government intervention as the shareholders is included in determining the distribution and price of oil and natural gas. The facts found that the Government has set the price of oil as shown in the Oil Price Increase in April 2018 is stipulated by the Minister of Energy and Mineral Resources no. $1811 \mathrm{~K} / 2 / \mathrm{MEM} / 2018$. Although the determination of the oil price is determined by the Minister of Energy and Mineral Resources does not act as a shareholder (the power of the government as Pertamina shareholder is the State Ministry of State-Owned Enterprises (SOEs)). The interference of the Government in determining the price of oil means that in terms of the principle of independent entity means the government has violated Pertamina's principle of independence. As a result of such violations, the government may be subject to sanctions ie the 
shareholder (Government) becomes responsible for the engagement made on behalf of Pertamina and is responsible for Pertamina's losses.

However, if the price fixing is associated with Article 3 Paragraph (3) of the 1945 Constitution and Oil and Gas Law and Oil and Gas Principles for the welfare of all Indonesians, then the determination of oil and gas prices by the government becomes a must. Since the 1945 Constitution has provided an adequate basis for the State/Government to utilize natural resources in the territory of the Republic of Indonesia is used for the welfare of all Indonesian people, including oil and natural gas. Oil and gas commodities shall be regulated and administered for their use, use, stock and maintenance by the State. This means there is a State intervention in managing oil and natural gas. Such interventions are included in the distribution and determination of oil and gas prices.

The challenge of other Pertamina Directors is the implementation of the Fiduciary duty law doctrine. The fiduciary duty doctrine is a doctrine that authorizes the Directors to manage the company according to the Company's objectives, business and objectives set forth in the Articles of Association professionally, ethically and by upholding Good Corporate Gouvance (GCG) with full responsibility. Pertamina's Board of Directors must reject any government interference with Pertamina's business. This doctrine also provides mandate and obligation for the Board of Directors to be unable to be interfered by shareholders including by the Government. The negligence of the Pertamina Board of Directors who refused to refuse government interference could be threatened to bear Pertamina's personal losses. However, based on the principle of oil and gas for the welfare of all the people of Indonesia, the determination of oil and gas prices by the government is a must.

\section{CONCLUSIONS AND SUGGESTIONS}

\section{A. Conclusions}

There is a dilemma for the Board of Directors of Pertamina, which is obliged to exercise the principle of independence of Limited Liability Company either as Limited Company or as Holding. The broad of director has to carry out the doctrine of fiduciary duty law which must perform its duty to manage the company pursuant to the intention, business and corporate objectives stipulated in the Articles of Association professionally, and by upholding Good Corporate Gouvance (GCG) with full responsibility. Based on these principles and doctrines, the Pertamina Board of Directors shall refuse to involve the shareholders (government) including the distribution and price of Oil and Gas determined by the shareholders and/or the government. The sanction of the Pertamina Board of Directors against this violation is personally liable.

However, on the other hand, the State/Government must utilize natural resources in the territory of the Republic of Indonesia for the welfare of all Indonesians, including oil and gas. Oil and gas commodities shall be regulated and administered for their use, use, stock and maintenance by the State. This means there is a State intervention in managing oil and natural gas. These interventions are included in the distribution and determination of the price of oil and natural gas that Pertamina has mandatory to run by Pertamina.

\section{B. Suggestions}

In the end, this legal research was conducted to reveal the above mentioned legal issues whose outcome was to provide a description of what should be done. Oil and natural gas is managed for the welfare of all Indonesian people based on the 1945 Constitution which the notion is fundamental to the establishment of the Unitary State of Indonesia. It is not possible to make changes. While the principle of limited company independence and fiduciary duty law doctrine, among others, comes from Article 3 Limited Liability Law (UPT) which is still very open for changes and/or additions.

Therefore, in order to provide legal certainty for the Board of Directors of Pertamina and Board of Directors of other Companies with the intention, objectives and business of the company concerning commodities of the interest life of the people, in Article 3 UPT needs to be amended and/or explanation. In essence, there are exceptions to the responsibilities set forth in Article 3 paragraph 2 of UPT which essentially the government is allowed to interfere in pricing and distribution of commodities concerning the livelihood of the people. In the implementation of the pricing and distribution is not the responsibility of the Board of Directors. With such an explanation, Pertamina's Board of Directors cannot be held responsible if there is a loss of Pertamina's company due to the government's interference and Pertamina's Board of Directors as well as the Government avoid the violation of the principle of independence of the limited liability company and the doctrine of fiduciary duty and the principle of oil and natural gas for welfare all the people of Indonesia.

As long as there is no change and/or addition of Article 3 UPT, it is a challenge for Pertamina Board of Directors in applying the principle of independence of limited liability company and Fiduciary duty legal doctrine to be able to harmonize with Oil and Gas commodity as the livelihood of the people and for the welfare of all people Indonesia.

\section{REFERENCES}

[1] "No Title." [Online]. Available: http://www.pertamina.com.id.

[2] R. Prasetya, Kedudukan Mandiri Perseroan Terbatas, Disertai Dengan Ulasan Menurut Undang-undang No. 1 tahun 1995. Bandung: PT. Citra Aditya Bakti, 2001.

[3] F. B. G. Tumbuan, "Tugas dan Tanggung Jawab Direksi Perseroan Terbatas," in Materi Pendidikan Singkat Hukum Bisnis, Jakarta: Unika AtmaJaya, 2000.

[4] P. M. Marzuki, Penelitian hukum. Jakarta: Kencana, 2007.

[5] T. M. Franck, The New Development : Can American Law and Legal Institutions Help Developmant Countries. 1971.

[6] T. Widiyono, "Tanggung Jawab Hukum Ultimate Share Holder dalam Group Perusahaan," Brawijaya University, 2015.

[7] H. C. Black, Black's Law Dictionary, Sixth. ST. Paul: West Publishing Co, 1990.

[8] Chatamarrasjid, Menyingkap Tabir Perseroan. Bandung: PT Citra Aditya Bakti, 2000.

[9] R. I. . Widjaya, Hukum Perusahaan. Jakarta: Megapoin, 2000.

[10] M. Fuady, Teori Negara Hukum Modern (Rechtstaat). Jakarta: Refika Aditama, 2011.

[11] L. J.Kurniawan, O. Sukmana, Abdussalam, and Maduki, Negara Kesejahteraan dan Pelayanan Sosial. Malang: Intrans Publishing, 2011.

[12] "No Title." [Online]. Available: https://www.pertamina.com/. [Accessed: 26-Apr-2018]. 